\title{
Deep brain stimulation treatment in dystonia: a bibliometric analysis
}

\author{
Estimulação cerebral profunda no tratamento de distonia: uma análise bibliométrica \\ Clarice LISTIK', Eduardo LISTIK², Rubens Gisbert CURY', Egberto Reis BARBOSA', \\ Manoel Jacobsen TEIXEIRA³, Daniel Ciampi de ANDRADE',3
}

\begin{abstract}
Background: Dystonia is a heterogeneous disorder that, when refractory to medical treatment, may have a favorable response to deep brain stimulation (DBS). A practical way to have an overview of a research domain is through a bibliometric analysis, as it makes it more accessible for researchers and others outside the field to have an idea of its directions and needs. Objective: To analyze the 100 most cited articles in the use of DBS for dystonia treatment in the last 30 years. Methods: The research protocol was performed in June 2019 in Elsevier's Scopus database, by retrieving the most cited articles regarding DBS in dystonia. We analyzed authors, year of publication, country, affiliation, and targets of DBS. Results: Articles are mainly published in Movement Disorders (19\%), Journal of Neurosurgery (9\%), and Neurology (9\%). European countries offer significant contributions (57\% of our sample). France (192.5 citations/paper) and Germany (144.1 citations/ paper) have the highest citation rates of all countries. The United States contributes with $31 \%$ of the articles, with 129.8 citations/paper. The publications are focused on General outcomes (46\%), followed by Long-term outcomes (12.5\%), and Complications (11\%), and the leading type of dystonia researched is idiopathic or inherited, isolated, segmental or generalized dystonia, with $27 \%$ of articles and 204.3 citations/ paper. Conclusions: DBS in dystonia research is mainly published in a handful of scientific journals and focused on the outcomes of the surgery in idiopathic or inherited, isolated, segmental or generalized dystonia, and with globus pallidus internus as the main DBS target.
\end{abstract}

Keywords: Bibliometrics; Deep Brain Stimulation; Dystonia.

\section{RESUMO}

Introdução: A distonia é uma doença heterogênea que, quando refratária ao tratamento medicamentoso, pode ter uma resposta favorável à estimulação encefálica profunda (EEP). Uma forma prática de ter uma visão desta área de pesquisa é por meio de análise bibliométrica, pois permite aos pesquisadores e terceiros a terem uma ideia das tendências e necessidades da área. Objetivo: Analisar os 100 artigos mais citados no tratamento de distonia pelo uso de EEP nos últimos 30 anos. Métodos: 0 protocolo de pesquisa foi realizado em junho de 2019 através da base de dados Scopus da Elsevier, em que se obteve os artigos mais citados na área de tratamento de distonia com EEP. Analisaram-se variáveis como autores, ano de publicação, país, afiliação, e alvos de EEP. Resultados: Os artigos foram principalmente publicados principalmente na Movement Disorders (19\%), no Journal of Neurosurgery (9\%), e na Neurology (9\%). Os países europeus oferecem contribuições significativas ( $57 \%$ da amostra). A França (192,5 citações/artigo) e a Alemanha (144,1 citações/artigo) possuem as mais altas taxas de citações dentre todos os países. Os Estados Unidos contribuem com 31\% dos artigos da amostra (129,8 citações/artigo). As publicações focaram em Desfechos gerais (46\%), seguido de Desfechos a longo prazo (12,5\%), e Complicações (11\%). 0 principal tipo de distonia pesquisado foi distonia generalizada ou segmentar, idiopática ou hereditária, isolada, abrangendo 27\% dos artigos e 204,3 citações/ artigo. Conclusões: A pesquisa de EEP em distonia é publicada em seletos periódicos científicos e foca nos desfechos da cirurgia, nas distonias generalizadas ou segmentares, idiopáticas ou hereditárias, isoladas, sendo o globus pallidus internus o principal alvo da EEP.

Palavras-chave: Bibliometria; Estimulação Encefálica Profunda; Distonia.

\section{INTRODUCTION}

Dystonia is a heterogeneous movement disorder characterized by sustained or intermittent muscle contractions leading to abnormal movements and postures ${ }^{1}$. It can be classified by its clinical characteristics, including body distribution (focal, segmental, multifocal, generalized, or hemidystonia) and associated features (isolated or combined); and etiology (idiopathic, inherited or acquired) ${ }^{1}$. The treatment of dystonia is aimed at providing symptomatic relief for the

\footnotetext{
${ }^{1}$ Universidade de São Paulo, Departamento de Neurologia, Centro de Distúrbios do Movimento, São Paulo SP, Brazil.

${ }^{2}$ Universidade Federal de São Paulo, Departamento de Bioquímica, São Paulo SP, Brazil.

${ }^{3}$ Instituto do Câncer do Estado de São Paulo, Centro de Dor, São Paulo SP, Brazil.

Clarice LISTIK (D) https://orcid.org/0000-0002-7660-3970; Eduardo LISTIK (iD https://orcid.org/0000-0002-2586-8282;

Rubens Gisbert CURY (D) https://orcid.org/0000-0001-6305-3327; Daniel Ciampi de ANDRADE (D) https://orcid.org/0000-0003-3411-632X

Correspondence: Clarice Listik; E-mail: clarice.listik@gmail.com

Conflict of interest: There is no conflict of interest to declare.
}

Received on November 15, 2019; Received in its final form on December 30, 2019; Accepted on January $27,2020$. 
motor symptoms, improving pain, and avoiding musculoskeletal complications such as joint contractures ${ }^{2}$. Medical treatment is usually limited to the side effects and has small symptomatic relief ${ }^{3}$. Botulinum toxin is a good option for focal dystonia; however, in generalized and segmental dystonia, it may have a limited effect due to its dose limits.

In general, most dystonic patients are selected for surgical treatment when the pharmacological treatment has revealed inadequate response; therefore, an individualized approach is the norm. Ablative procedures were largely performed in dystonia, before the advent of deep brain stimulation (DBS). Nowadays, pallidotomy is usually an option, for instance in acquired static dystonia and in status dystonicus. DBS should be considered in the inherited or idiopathic generalized dystonias that do not have reasonable symptomatic control with medication and in which disabilities impact patient's QoL. In inherited or idiopathic segmental and focal dystonias and other acquired forms like tardive dyskinesia or cerebral palsy, it should be considered when refractory to pharmacological treatments ${ }^{2}$. DBS, usually targeting the globus pallidus internus (GPi), has a response in idiopathic or inherited isolated segmental or generalized dystonia that varies between $43-65 \%^{2}$. GPi is the most common target; however, initially, thalamic targets were used ${ }^{2}$. Recently, the subthalamic nucleus (STN) is also being considered a viable target ${ }^{4,5}$.

A practical way to identify which are the most influential authors, journals, and countries in a particular field is through a bibliometric analysis ${ }^{6}$. It makes it more accessible for researchers and others outside the field to have an overview of its directions and needs ${ }^{7}$. The literature does present bibliometric analysis on various themes, such as neurocritical care ${ }^{6}$, back pain ${ }^{8}$, essential tremor ${ }^{7}$, Parkinson's disease ${ }^{9}$, and deep brain stimulation ${ }^{10}$.

We analyzed the 100 most cited articles on the use of DBS for dystonia treatment in the last 30 years. We evaluated authors' information, their affiliation, and the country of the corresponding author. Additionally, we investigated which were the most cited journals and their impact factors, the used DBS targets (when applicable), and the dystonia classification (also, when applicable). Articles were divided into primary or secondary (i.e., reviews and guidelines) articles.

\section{METHODS}

\section{Search protocol}

The used database for article selection was Elsevier's Scopus, and the search protocol was performed in June 2019. The exact input was TITLE ("dystonia" AND ("DBS" OR "Deep brain stimulation")) OR ABS ("dystonia" AND ("DBS" OR "Deep brain stimulation")) AND PUBYEAR>1988. This terminology translated to publications which possessed the terms dystonia and DBS or deep brain stimulation in either the article's title or abstract and have been published in the last 30 years (i.e., since 1989). After screening the search results based on pertinence, the 100 most cited were used in this study. Impact factor (IF) data of journals were retrieved from InCites Journal Citation Reports (Clarivate Analytics), and both 2017 IF and 5-year IF were collected. Lastly, the $h$ index of authors was obtained from Scopus, as well.

\section{Bibliometric analysis}

After selecting the 100 most cited articles, we obtained additional information regarding these publications within our sample. At first, all the authors, year of publication, journal and its impact factor, country, and affiliation of the corresponding author were retrieved. All articles were also categorized, when mentioned, regarding the targets of DBS. The publications were divided into primary researches (i.e., original articles) and secondary researches, such as reviews, and guidelines; the classification of dystonia, if applicable; and into specific themes, such as complications, outcomes, pathophysiology, physiology, surgical approach, targets, ethics, types of stimulation and treatment. Categorized articles in outcomes were further classified into general aspects, longterm outcomes, dystonic tremor outcomes, and predictors of outcome.

\section{RESULTS}

\section{General results}

Our search led to 337 hits ranging from zero to 679 citations (mean of 30.2). The 100 most cited articles have a mean of 130.4 citations (70-679), and the top 10, a mean of 311.2 (203-679), which have been detailed in Table 1. The most cited article was from Vidailhet et al. ${ }^{11}$.

\section{Journals and impact factor}

Movement Disorders (2017 IF=8.324) accounts for 19 of the articles in our sample, summing up 2071 citations, and 12 articles were from primary research (1,262 citations). New England Journal of Medicine (2017 IF=79.260) was the second most cited journal while having only two articles in the top 100, both of them from primary research; they were cited 1276 times. The Journal of Neurosurgery was the third most cited journal, with nine publications, all of them from primary research. This material accounted for 1,247 citations.

\section{Country and affiliation}

All of the corresponding author countries in our samples were from the Northern Hemisphere. They were divided primarily in Europe and North America, but also in Asia. "DBS in dystonia" research is highly prevalent in Europe, which accounted for 57 articles in our sample. Germany, France, and the United Kingdom display a large production of 
material. Germany accounted for 25 articles (3,203 citations), 18 from primary research (2,438 citations). France summed up to 15 articles (2,647 citations), 12 from primary research $(2,309)$. Moreover, the United Kingdom had 10 articles (1,086 citations), in which eight were from primary research. The United States was another country in which publications were majorly present. The country has the most articles than any other in the sample: 31 articles (3,834 citations), 19 from primary research (2,466 citations).

The most prolific affiliations are the University of Sorbonne (France), the Kiel University (Germany), and the University of Montpellier (France). The three institutions account for $16 \%$ of the 100 most cited articles in "DBS in dystonia”. Both University of Sorbonne and Kiel University display five articles, although the first has four primary research publications, and the latter two. However, the total citations from the University of Sorbonne are 1,300 (1,221 from primary research), and the Kiel University 1,036 (696 from primary research). The University of Montpellier has six articles, all of them from primary research, summing up 789 citations.

\section{Year}

Although we researched articles since 1989, the most cited ones were only included from 1999 on. After then, all years, until 2014, had highly cited publications, with a peak from 2005-2007, in which $33 \%$ of our sample's articles reside, summing up to $39 \%$ of total citations.

\section{Authors}

The three most cited first authors were Vidailhet ( $h$ index of 66), Kupsch ( $h$ index of 63), and Volkmann ( $h$ index of 61), as seen in Table 2. The three altogether represent $18 \%$ of all citations in our sample. Vidailhet displayed four articles (1,222 citations), three from primary research (1,143 citations). Kupsch has a single highly cited, primary research article with 597 citations. Lastly, Volkmann had four articles (547 citations), two of which were from primary research (256 citations).

Another analysis was performed according to any placement of authors during publications. In this analysis, the most cited authors were Pollak ( $h$ index of 83), Volkmann ( $h$ index of 61), and Benabid ( $h$ index of 88). Pollak appeared in seven articles (1,646 citations), six from primary research (1,520 citations). Volkmann was included in nine publications (1,625 citations), five of which are primary research articles (1,334 citations). Benabid was in six articles (1,568 citations), five of which were from primary research (1,442 citations).

Table 1. Top ten cited publications in deep brain stimulation in dystonia.

\begin{tabular}{|c|c|c|c|c|c|}
\hline First author & Title & Year & Journal & Country & Citations \\
\hline Vidailhet $^{11}$ & $\begin{array}{l}\text { Bilateral deep-brain stimulation of the globus } \\
\text { pallidus in primary generalized dystonia }\end{array}$ & 2005 & $\begin{array}{l}\text { New England } \\
\text { Journal of Medicine }\end{array}$ & France & 679 \\
\hline$K_{\text {Kupsch }}^{12}$ & $\begin{array}{l}\text { Pallidal deep-brain stimulation in primary } \\
\text { generalized or segmental dystonia }\end{array}$ & 2006 & $\begin{array}{l}\text { New England } \\
\text { Journal of Medicine }\end{array}$ & Germany & 597 \\
\hline Coubes $^{13}$ & $\begin{array}{l}\text { Electrical stimulation of the globus pallidus } \\
\text { internus in patients with primary generalized } \\
\text { dystonia: Long-term results }\end{array}$ & 2004 & $\begin{array}{l}\text { Journal of } \\
\text { Neurosurgery }\end{array}$ & France & 287 \\
\hline Vidailhet $^{14}$ & $\begin{array}{l}\text { Bilateral, pallidal, deep-brain stimulation in } \\
\text { primary generalised dystonia: a prospective } \\
\text { 3-year follow-up study }\end{array}$ & 2007 & Lancet Neurology & France & 266 \\
\hline Vercueil 15 & $\begin{array}{c}\text { Deep brain stimulation in the treatment of } \\
\text { severe dystonia }\end{array}$ & 2001 & Journal of Neurology & France & 227 \\
\hline Kumar $^{16}$ & $\begin{array}{l}\text { Globus pallidus deep brain } \\
\text { stimulation for generalized dystonia: } \\
\text { Clinical and pet investigation }\end{array}$ & 1999 & Neurology & USA & 220 \\
\hline Albanese $^{17}$ & $\begin{array}{l}\text { EFNS guidelines on diagnosis and } \\
\text { treatment of primary dystonias }\end{array}$ & 2011 & $\begin{array}{l}\text { European Journal } \\
\text { of Neurology }\end{array}$ & Italy & 214 \\
\hline Volkmann ${ }^{18}$ & $\begin{array}{l}\text { Introduction to the programming } \\
\text { of deep brain stimulators }\end{array}$ & 2002 & Movement Disorders & Germany & 213 \\
\hline Okun ${ }^{19}$ & $\begin{array}{l}\text { Management of referred deep brain } \\
\text { stimulation failures: A retrospective analysis } \\
\text { from } 2 \text { Movement Disorders Centers }\end{array}$ & 2005 & $\begin{array}{l}\text { Archives of } \\
\text { Neurology }\end{array}$ & USA & 206 \\
\hline Beric $^{20}$ & $\begin{array}{l}\text { Complications of deep } \\
\text { brain stimulation surgery }\end{array}$ & 2002 & $\begin{array}{l}\text { Stereotactic } \\
\text { and Functional } \\
\text { Neurosurgery }\end{array}$ & USA & 203 \\
\hline
\end{tabular}




\section{Categories}

The articles were then categorized, and primary research articles accounted for $72 \%$ of our samples. The most present categories were articles that discussed General outcomes from DBS, which included 33 articles (5,044 citations). We separated from these general overviews the ones that investigated the Long-term Outcomes (more than 18 months), which was the second most discussed topic ( 9 articles, 1,327 citations). The third most present category was Complications, which had eight articles summing 996 citations.

The other 28 articles in our sample were from secondary research; most of them were Reviews, and only one a Guideline. Most of the secondary researches focused on Treatment aspects using DBS (13 articles, 1,508 citations), and other minor focus were given to Pathophysiology (3 articles, 388 citations) and General outcomes (3 articles, 294 citations).

\section{DBS Targets}

As reported in Figure 1, we detailed how DBS targets were applied in the different publications listed in the 100 most cited articles in "DBS in dystonia". There were 31 articles in which this analysis was not applicable, as the target was either not mentioned or DBS treatment was not specified in a general manner. Doubtlessly, the most mentioned target was the GPi, which appeared in 60 articles (8,255 citations), 54 of which being from primary research (7,662 citations).
Thalamic targets were, then, the most present ones. In total, 10 articles mentioned thalamic targets: five of which did not specify a precise target, three focused on the Ventral intermediate nucleus (VIM), one on the Ventrolateral thalamic nucleus (VLp), and one on the Ventral-oralis complex (Vo). The total citations for thalamic targets were 1,126. Additionally, seven articles were focusing on the Subthalamic nucleus (STN, 663 citations), five of which were from primary research (461 citations). One primary research article focused on the Caudal Zona Incerta (cZi) and had 143 citations.

\section{Dystonia classification}

In the most cited articles, the description of dystonia classification was only observed in primary articles (Table 3 ). A fraction of them (18, under Miscellaneous) did present different kinds of dystonia in the study. The most common dystonia investigated was idiopathic or inherited, isolated, segmental or generalized dystonia, which presented 16 articles (3,269 citations), followed by idiopathic, isolated, focal dystonia, with 11 publications (1,238 citations).

\section{DISCUSSION}

Our analysis indicated that the 10 most cited journals in DBS in dystonia accounted for almost three-quarters of

Table 2. Ten most cited first authors and all authors in deep brain stimulation in dystonia research.

\begin{tabular}{|c|c|c|c|c|}
\hline Type of authorship & First author & $\begin{array}{l}\text { Number of articles in the } \\
\text { top } 100 \text { (primary research) }\end{array}$ & $\begin{array}{l}\text { Number of citations } \\
\text { (primary research) }\end{array}$ & $\mathrm{h}$ index \\
\hline \multirow{10}{*}{ First authorship } & Vidailhet ${ }^{11,14,21,22}$ & $4(3)$ & $1,222(1,143)$ & 66 \\
\hline & Kupsch ${ }^{12}$ & $1(1)$ & $597(597)$ & 63 \\
\hline & Volkmann ${ }^{18,23,24,25}$ & $4(2)$ & $547(256)$ & 61 \\
\hline & Krauss $26,27,28,29$ & $4(2)$ & $514(271)$ & 50 \\
\hline & Jankovic ${ }^{30,31,32}$ & $3(0)$ & $424(0)$ & 126 \\
\hline & Albanese $e^{17,33}$ & $2(0)$ & $412(0)$ & 63 \\
\hline & Coubes $^{13,34}$ & $2(2)$ & $363(363)$ & 32 \\
\hline & Ostrem $35,36,37$ & $3(2)$ & $354(228)$ & 31 \\
\hline & $\mathrm{Cif}^{38,39,40}$ & $3(3)$ & $294(294)$ & 20 \\
\hline & Kumar ${ }^{16,41}$ & $2(1)$ & $284(220)$ & 44 \\
\hline \multirow{10}{*}{ Any authorship } & Pollak ${ }^{11,14,15,21}$ & $7(6)$ & $1,646(1,520)$ & 83 \\
\hline & Volkmann $12,18,23,24,25,42,43,44,45$ & $9(7)$ & $1,625(1,334)$ & 61 \\
\hline & Benabid $11,14,15,21,46,47$ & $6(5)$ & $1,568(1,442)$ & 88 \\
\hline & Vercueil $11,14,15,46,47,48,49$ & $7(5)$ & $1,524(1,322)$ & 25 \\
\hline & Schneider $r^{12,24,25,43,45,50,51,52,53}$ & $9(9)$ & $1,430(1,430)$ & 47 \\
\hline & Vidailhet $11,14,21,22,47,49$ & $6(5)$ & $1,372(1,293)$ & 66 \\
\hline & Kupsch $12,24,25,43,45,51,52,53$ & $8(7)$ & $1,356(1,356)$ & 63 \\
\hline & Krauss ${ }^{17,24,26,27,28,29,33,50,54,55,56,58}$ & $10(6)$ & $1,302(647)$ & 50 \\
\hline & Agid $^{11,14,21,49}$ & $4(3)$ & $1,221(1,023)$ & 121 \\
\hline & Ardouin 11,14,21,49 & $4(4)$ & $1,221(1,221)$ & 26 \\
\hline
\end{tabular}


all articles and citations in our sample. They are majorly published in Movement Disorders (19\%), the Journal of Neurosurgery (9\%), Neurology (9\%), Brain (8\%), and The Lancet Neurology (7\%). However, the journals with most cited articles were the New England Journal of Medicine (average of 638 citations per paper), The Lancet Neurology (152.1 citations/paper), and the European Journal of Neurology (146.5 citations/paper).

DBS in dystonia is mainly researched in the Northern Hemisphere. In the top 100 most cited articles in this theme, there were no countries outside of it. European countries offer significant contributions (57\% of our sample). France and Germany have the highest citation rates of all countries. When considering primary research articles, France displays 192.5 citations/paper, and Germany 144.1 citations/paper. The United States also contributes to $31 \%$ of the articles, with 129.8 citations/paper.

Most primary research articles focus on General outcomes (46\%), followed by Long-term outcomes (12.5\%), and Complications (11\%). Few publications in our sample tried to find Predictors of outcome (2.8\%) or compared different Targets (1.4\%). When we analyzed the used DBS targets for dystonia treatment, the classic GPi corresponded to $77 \%$ of the publications, $S T N$, which is a hopeful new option of treatment $t^{4,55}$, totalized $9 \%$, and thalamic targets $13 \%$, though mainly used for dystonic tremor ${ }^{56,57}$.

As expected, most articles analyzed idiopathic or inherited, isolated, segmental or generalized dystonia ( $27 \%$ with an average of 204.3 citations/paper), which is the most studied kind of dystonia and has, usually, the most improvement after DBS treatment ${ }^{58}$. Idiopathic, isolated, focal dystonia is also highly prevalent (18.5\%, 112.6 citations/paper) in our sample.

Similarly to other bibliometric analysis, our study has limitations. Scopus possesses greater coverage and specificity when compared to Web of Science and Google Scholar; however, we employed it as a single database for article retrieval ${ }^{6,59,60}$. Moreover, articles published after 2014 did not displayed in our sample, possibly because more recent articles are still accumulating citations. Nevertheless, this context does not undervalue their potential.

DBS in dystonia research is mainly focused on selected, Northern Hemisphere countries. They are mostly published in a handful of scientific journals and mainly focusing on outcomes of the surgery, with GPi as DBS target, and in idiopathic or inherited, isolated, segmental or generalized dystonia. This bibliometric analysis might assist unfamiliar researchers and practitioners in obtaining an overview of this particular domain.

Table 3. Citation and publication profile according to the type of dystonia in the 100 most cited articles in deep brain stimulation in dystonia research.

\begin{tabular}{ccc}
\hline Dystonia classification & $\begin{array}{c}\text { Number } \\
\text { of articles } \\
\text { (primary }\end{array}$ & $\begin{array}{c}\text { Number of } \\
\text { citations } \\
\text { (primary } \\
\text { research) }\end{array}$ \\
research)
\end{tabular}

Idiopathic or inherited, isolated, segmental or generalized $\quad$ 3,269 (3269) dystonia

\begin{tabular}{|c|c|c|}
\hline $\begin{array}{l}\text { Idiopathic, isolated, focal } \\
\text { dystonia }\end{array}$ & $11(11)$ & $1,238(1238)$ \\
\hline Acquired dystonia & $7(7)$ & 759 (759) \\
\hline Combined dystonia & $5(5)$ & $416(416)$ \\
\hline $\begin{array}{l}\text { Dystonia associated with } \\
\text { other neurological or systemic } \\
\text { manifestations }\end{array}$ & $2(2)$ & $250(250)$ \\
\hline Miscellaneous & $18(18)$ & 2,133 (2133) \\
\hline Not applicable & $41(13)$ & $4,973(1644)$ \\
\hline
\end{tabular}

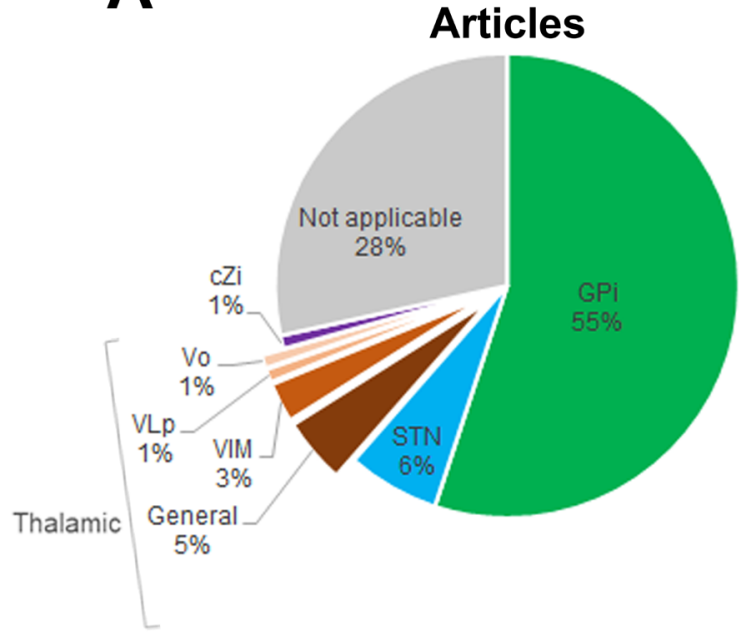

\section{B}

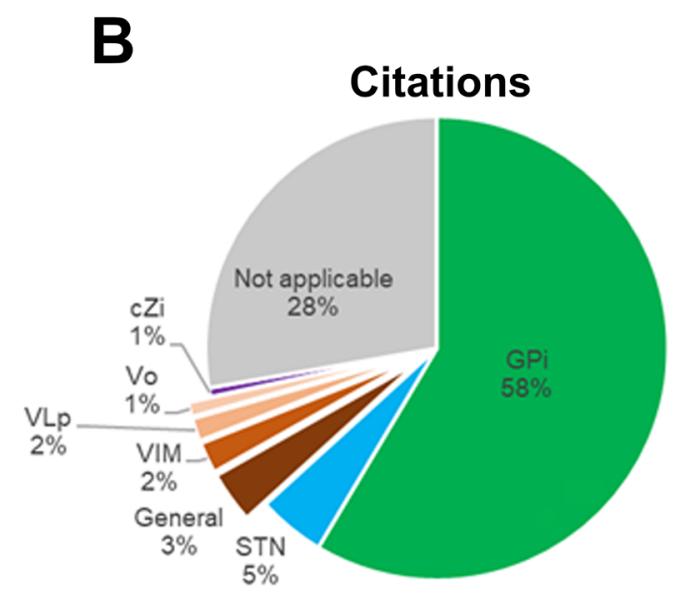

Figure 1. Pie charts indicating the distribution of (A) articles and (B) citations for different deep brain stimulation targets. 


\section{References}

1. Albanese A, Bhatia K, Bressman SB, Delong MR, Fahn S, Fung VS, et al. Phenomenology and classification of dystonia: a consensus update. Mov Disord. 2013 Jun;28(7):863-73. https://doi.org/10.1002/ mds. 25475

2. Cury RG, Kalia SK, Shah BB, Jimenez-Shahed J, Prashanth LK, Moro E. Surgical treatment of dystonia. Expert Rev Neurother. 2018 May;18(6):477-92. https://doi.org/10.1080/14737175.2018.1478288

3. Comella CL. Dystonia:Then and now. Parkinsonism Relat Disord. 2018 Jan;46 Suppl 1:S66-S69. https://doi.org/10.1016/j. parkreldis.2017.06.025

4. Lin S, Wu Y, Li H, Zhang C, Wang T, Pan Y, et al. Deep brain stimulation of the globus pallidus internus versus the subthalamic nucleus in isolated dystonia. J Neurosurg. 2019 Mar:1-12. https://doi. org/10.3171/2018.12.JNS181927

5. Schjerling L, Hjermind LE, Jespersen B, Madsen FF, Brennum $J$, Jensen SR, Let al. A randomized double-blind crossover trial comparing subthalamic and pallidal deep brain stimulation for dystonia. J J Neurosurg. 2013 Dec;119(6):1537-45. https://doi. org/10.3171/2013.8.JNS13844

6. Ramos MB, Koterba E, Rosi Junior J, Teixeira MJ, Figueiredo EG. A Bibliometric analysis of the most cited articles in Neurocritical Care Research. Neurocrit Care. 2019 Oct;31(2):365-72. https://doi. org/10.1007/s1 2028-019-00731-6

7. King NK, Tam J, Fasano A, Lozano AM. The most cited works in Essential Tremor and Dystonia. Tremor Other Hyperkinet Mov (N Y). 2016 Apr;6:310. https://doi.org/10.7916/D8NG4QHP

8. Huang W, Wang L, Wang B, Yu L, Yu X. Top 100 cited articles on back pain research: a citation analysis. Spine (Phila $\mathrm{Pa}$ 1976). 2016 Nov;41(21):1683-92. https://doi.org/10.1097/ BRS.0000000000001736

9. Xue JH, Hu ZP, Lai P, Cai DQ, Wen ES. The 100 most-cited articles in Parkinson's disease. Neurol Sci. 2018 Sep;39(9):1537-45. https://doi. org/10.1007/s10072-018-3450-y

10. Hu K, Moses ZB, Xu W, Williams Z. Bibliometric profile of deep brain stimulation. Br J Neurosurg. 2017 Oct;31 (5):587-92. https://doi.org/1 $0.1080 / 02688697.20171324109$

11. Vidailhet M, Vercueil L, Houeto JL, Krystkowiak P, Benabid AL, Cornu $P$, et al. Bilateral deep-brain stimulation of the globus pallidus in primary generalized dystonia. N Engl J Med. 2005 Feb;352(5):459-67. https://doi.org/10.1056/NEJMoa042187

12. Kupsch A, Benecke R, Müller J, Trottenberg T, Schneider GH, Poewe $W$, et al. Pallidal deep-brain stimulation in primary generalized or segmental dystonia. N Engl J Med. 2006 Nov;355(19):1978-90. https://doi.org/10.1056/NEJMoa063618

13. Coubes P, Cif L, El Fertit H, Hemm S, Vayssiere N, Serrat S, et al. Electrical stimulation of the globus pallidus internus in patients with primary generalized dystonia: long-term results. J Neurosurg. 2004 Aug;101(2):189-94. https://doi.org/10.3171/jns.2004.101.2.0189

14. Vidailhet M, Vercueil L, Houeto JL, Krystkowiak P, Lagrange C, Yelnik J, et al. Bilateral, pallidal, deep-brain stimulation in primary generalised dystonia: a prospective 3 year follow-up study. Lancet Neurol. 2007 Mar;6(3):223-9. https://doi.org/10.1016/S14744422(07)70035-2

15. Vercueil L, Pollak P, Fraix V, Caputo E, Moro E, Benazzouz A, et al. Deep brain stimulation in the treatment of severe dystonia.J Neurol. 2001 Aug;248(8):695-700. https://doi.org/10.1007/s004150170116

16. Kumar R, Dagher A, Hutchison WD, Lang AE, Lozano AM. Globus pallidus deep brain stimulation for generalized dystonia: Clinical and pet investigation. Neurology. 1999 Sep;53(4):871-4. https://doi. org/10.1212/wnl.53.4.871

17. Albanese A, Asmus F, Bhatia KP, Elia AE, Elibol B, Filippini G, et al. EFNS guidelines on diagnosis and treatment of primary dystonias.
Eur J Neurol. 2011 Jan;18(1):5-18. https://doi.org/10.1111/j.14681331.2010.03042.x

18. Volkmann J, Herzog J, Kopper F, Deuschl G. Introduction to the programming of deep brain stimulators. Mov Disord. 2002;17 Suppl 3:S181-7. https://doi.org/10.1002/mds.10162

19. Okun MS, Tagliati M, Pourfar M, Fernandez HH, Rodriguez RL, Alterman RL, et al. Management of referred deep brain stimulation failures: a retrospective analysis from 2 movement disorders centers. Arch Neurol. 2005 Aug;62(8):1250-5. https://doi.org/10.1001/ archneur.62.8.noc40425

20. Beric A, Kelly PJ, Rezai A, Sterio D, Mogilner A, Zonenshayn M, et al. Complications of deep brain stimulation surgery. Stereotact Funct Neurosurg. 2001;77(1-4):73-8. https://doi.org/10.1159/000064600

21. Vidailhet M, Yelnik J, Lagrange C, Fraix V, Grabli D, Thobois S, et al. Bilateral pallidal deep brain stimulation for the treatment of patients with dystonia-choreoathetosis cerebral palsy: a prospective pilot study. Lancet Neurol. 2009 Aug;8(8):709-17. https://doi.org/10.1016/ S1474-4422(09)70151-6

22. Vidailhet M, Jutras MF, Grabli D, Roze E. Deep brain stimulation for dystonia. J Neurol Neurosurg Psychiatry. 2013;84(9):1029-42. http:// dx.doi.org/10.1136/jnnp-2011-301714

23. Volkmann J, Benecke R. Deep brain stimulation for dystonia: Patient selection and evaluation. Mov Disord. 2002;17 Suppl 3:S112-5. https://doi.org/10.1002/mds.10151

24. Volkmann J, Mueller J, Deuschl G, Kühn AA, Krauss JK, Poewe $W$, et al. Pallidal neurostimulation in patients with medicationrefractory cervical dystonia: A randomised, sham-controlled trial. Lancet Neurol. 2014 Sep;13(9):875-84. https://doi.org/10.1016/ S1474-4422(14)70143-7

25. Volkmann J, Wolters A, Kupsch A, Müller J, Kühn AA, Schneider $\mathrm{GH}$, et al. Pallidal deep brain stimulation in patients with primary generalised or segmental dystonia: 5-year follow-up of a randomised trial. Lancet Neurol. 2012 Dec;11(12):1029-38. https://doi. org/10.1016/S1474-4422(12)70257-0

26. Krauss JK, Jankovic J. Head injury and posttraumatic movement disorders. Neurosurgery. 2002 May;50(5):927-39; discussion 939-40. https://doi.org/10.1097/00006123-200205000-00003

27. Krauss JK, Loher TJ, Pohle T, Weber S, Taub E, Bärlocher CB, et al. Pallidal deep brain stimulation in patients with cervical dystonia and severe cervical dyskinesias with cervical myelopathy. J J Neurol Neurosurg Psychiatry. 2002 Feb;72(2):249-56. https://doi. org/10.1136/jnnp.72.2.249

28. Krauss JK, Loher TJ, Weigel R, Capelle HH, Weber S, Burgunder JM. Chronic stimulation of the globus pallidus internus for treatment of non-DYT1 generalized dystonia and choreoathetosis: 2-Year follow up.J Neurosurg. 2003 Apr;98(4):785-92. https://doi.org/10.3171/ jns.2003.98.4.0785

29. Krauss JK, Yianni J, Loher TJ, Aziz TZ. Deep Brain Stimulation for Dystonia. JJ Clin Neurophysiol. 2004 Jan/Feb;21(1):18-30. https:// doi.org/10.1097/00004691-200401000-00004

30. Jankovic J. Treatment of dystonia. Lancet Neurol 2006 Oct;5(10):864-72. https://doi.org/10.1016/S1474-4422(06)70574-9

31. Jankovic J. Medical treatment of dystonia. Mov Disord. 2013 Jun;28(7):1001-12. https://doi.org/10.1002/mds.25552

32. Jankovic J. Treatment of hyperkinetic movement disorders. Lancet Neurol. 2009 Sep;8(9):844-56. https://doi.org/10.1016/S14744422(09)70183-8

33. Albanese A, Barnes MP, Bhatia KP, Fernandez-Alvarez E, Filippini G, Gasser T, et al. A systematic review on the diagnosis and treatment of primary (idiopathic) dystonia and dystonia plus syndromes: Report of an EFNS/MDS-ES Task Force. Eur J Neurol. 2006 May;13(5):433-44. https://doi.org/10.1111/j.1468-1331.2006.01537.x 
34. Coubes P, Vayssiere N, El Fertit H, Hemm S, Cif L, Kienlen J, et al. Deep brain stimulation for dystonia: Surgical technique. Stereotact Funct Neurosurg. 2002;78(3-4):183-91. https://doi. org/10.1159/000068962

35. Ostrem JL, Marks Jr WJ, Volz MM, Heath SL, Starr PA. Pallidal deep brain stimulation in patients with cranial-cervical dystonia (Meige syndrome). Mov Disord. 2007 Oct;22(13):1885-91. https://doi. org/10.1002/mds. 21580

36. Ostrem JL, Racine CA, Glass GA, Grace JK, Volz MM, Heath SL, et al. Subthalamic nucleus deep brain stimulation in primary cervical dystonia. Neurology. 2011 Mar;76(10):870-8. https://doi.org/10.1212/ WNL.0b013e31820f2e4f

37. Ostrem JL, Starr PA. Treatment of dystonia with deep brain stimulation. Neurotherapeutics. 2008 Apr;5(2):320-30. https://doi. org/10.1016/j.nurt.2008.01.002

38. Cif L, Valente EM, Hemm S, Coubes C, Vayssiere N, Serrat S, et al. Deep brain stimulation in myoclonus-dystonia syndrome. Mov Disord. 2004 Jun;19(6):724-7. https://doi.org/10.1002/mds.20030

39. Cif L, Vasques X, Gonzalez V, Ravel P, Biolsi B, Collod-Beroud G, et al. Long-term follow-up of DYT1 dystonia patients treated by deep brain stimulation: An open-label study. Mov Disord. 2010 Feb;25(3):289-99. https://doi.org/10.1002/mds.22802

40. Cif L, El Fertit H, Vayssiere N, Hemm S, Hardouin E, Gannau A, et al. Treatment of dystonic syndromes by chronic electrical stimulation of the internal globus pallidus. J Neurosurg Sci. 2003 Mar;47(1):52-5.

41. Kumar R. Methods for programming and patient management with deep brain stimulation of the globus pallidus for the treatment of advanced parkinson's disease and dystonia. Mov Disord. 2002;17 Suppl 3:S198-207. https://doi.org/10.1002/mds.10164

42. Krause M, Fogel W, Kloss M, Rasche D, Volkmann J, Tronnier V. Pallidal stimulation for dystonia. Neurosurgery. 2004 Dec;55(6):1361-8; discussion 1368-70. https://doi.org/10.1227/01. neu.0000143331.86101.5e

43. Mueller J, Skogseid IM, Benecke R, Kupsch A, Trottenberg T, Poewe $W$, et al. Pallidal deep brain stimulation improves quality of life in segmental and generalized dystonia: Results from a prospective, randomized sham-controlled trial. Mov Disord. 2008 Jan;23(1):131-4. https://doi.org/10.1002/mds.21783

44. Timmermann L, Pauls KAM, Wieland K, Jech R, Kurlemann G, Sharma $\mathrm{N}$, et al. Dystonia in neurodegeneration with brain iron accumulation: outcome of bilateral pallidal stimulation. Brain. 2010 Mar;133(Pt 3):701-12. https://doi.org/10.1093/brain/awq022

45. Trottenberg T, Volkmann J, Deuschl G, Kühn AA, Schneider GH, Müller $J$, et al. Treatment of severe tardive dystonia with pallidal deep brain stimulation. Neurology. 2005 Jan;64(2):344-6. https://doi. org/10.1212/01.WNL.0000149762.80932.55

46. Benabid AL, Koudsié A, Benazzouz A, Vercueil L, Fraix V, Chabardes $S$, et al. Deep brain stimulation of the corpus luysi (subthalamic nucleus) and other targets in Parkinson's disease. Extension to new indications such as dystonia and epilepsy. J Neurol. 2001 Sep;248 Suppl 3:III37-47. https://doi.org/10.1007/ pl00007825
47. Detante O, Vercueil L, Thobois S, Broussolle E, Costes N, Lavenne F, et al. Globus pallidus internus stimulation in primary generalized dystonia: A H2 150 PET study. Brain. 2004 Aug;127(Pt 8):1899-908. https://doi.org/10.1093/brain/awh213

48. Krack P, Vercueil L. Review of the functional surgical treatment of dystonia. Eur J Neurol. 2001 Sep;8(5):389-99. https://doi. org/10.1046/j.1468-1331.2001.00231.x

49. Pillon B, Ardouin C, Dujardin K, Vittini P, Pelissolo A, Cottencin O, et al. Preservation of cognitive function in dystonia treated by pallidal stimulation. Neurology. 2006 May 23;66(10):1556-8. https://doi. org/10.1212/01.wnl.0000216131.41563.24

50. Barow E, Neumann WJ, Brucke C, Huebl J, Horn A, Brown P, et al. Deep brain stimulation suppresses pallidal low frequency activity in patients with phasic dystonic movements. Brain. 2014 Nov;137(Pt 11):3012-3024. https://doi.org/10.1093/brain/awu258

51. Gruber D, Kühn AA, Schoenecker T, Kivi A, Trottenberg T, Hoffmann $\mathrm{KT}$, et al. Pallidal and thalamic deep brain stimulation in myoclonusdystonia. Mov Disord. 2010 Aug;25(11):1733-43. https://doi. org/10.1002/mds.23312

52. Gruber D, Trottenberg T, Kivi A, Schoenecker T, Kopp UA, Hoffmann KT, et al. Long-term effects of pallidal deep brain stimulation in tardive dystonia. Neurology. 2009 Jul;73(1):53-8. https://doi.org/10.1212/ WNL.0b013e3181aaea01

53. Hälbig TD, Gruber D, Kopp UA, Schneider GH, Trottenberg T, Kupsch A. Pallidal stimulation in dystonia: effects on cognition, mood, and quality of life. J Neurol Neurosurg Psychiatry. 2005 Dec;76(12):1713-6. https://doi.org/10.1136/jnnp.2004.057992

54. Loher TJ, Capelle HH, Kaelin-Lang A, Weber S, Weigel R, Burgunder JM, et al. Deep brain stimulation for dystonia: outcome at long-term follow-up. J Neurol. 2008 Jun;255(6):881-4. https://doi.org/10.1007/ s00415-008-0798-6

55. Loher TJ, Hasdemir MG, Burgunder JM, Krauss JK. Long-term follow-up study of chronic globus pallidus internus stimulation for posttraumatic hemidystonia. J Neurosurg. 2000 Mar;92(3):457-60. https://doi.org/10.3171/jns.2000.92.3.0457

56. Moro E, Gross RE, Krauss JK. What's new in surgical treatment for dystonia? Mov Disord. 2013 Jun 15;28(7):1013-20. https://doi. org/10.1002/mds. 25550

57. Fasano A, Bove F, Lang AE. The treatment of dystonic tremor: a systematic review. J Neurol Neurosurg Psychiatry. 2014 Jul;85(7):759-69. https://doi.org/10.1136/jnnp-2013-305532

58. Moro E, LeReun C, Krauss JK, Albanese A, Lin JP, Walleser Autiero $S$, et al. Efficacy of pallidal stimulation in isolated dystonia: a systematic review and meta-analysis. Eur J Neurol. 2017 Apr;24(4):552-60. https://doi.org/10.1111/ene.13255

59. Falagas ME, Pitsouni El, Malietzis GA, Pappas G. Comparison of PubMed, Scopus, Web of Science, and Google Scholar: strengths and weaknesses. FASEB J. 2008 Feb;22(2):338-42. https://doi. org/10.1096/fj.07-9492LSF

60. Martín-Martín A, Orduna-Malea E, Thelwall M, López-Cózar ED. Google Scholar, Web of Science, and Scopus: a systematic comparison of citations in 252 subject categories. J Informetr. 2018;12(4):1160-77. https://doi.org/10.1016/j.joi.2018.09.002 